\title{
Ethnocultural specificity of the linguistic consciousness of the Sakha language speakers (by the example of the concept "culture")
}

\author{
Marina Kysylbaikova*, Luidmila Zamorshchikova, and Ninel Malysheva \\ M.K. Ammosov North-Eastern Federal University, 677027, Republic of Sakha (Yakutia), Russia
}

\begin{abstract}
This work presents the conceptualization of culture in an integrated manner, which did not have sufficient coverage and monographic description in linguistics based on the material of the Yakut language as a whole. Learning a language from different positions, namely from the point of view of a cognitive approach, helps to study the person himself: his intellectual, mental, social, ethno-national components, his linguistic consciousness. Psycholinguistic and ethnopsycholinguistic studies of linguistic consciousness, the study of the image of the world of an ethnic group are a new integrated approach. This approach, used in our study, differs in that it is aimed at identifying the ethnocultural specifics of the linguistic consciousness of the Sakha language speakers.
\end{abstract}

\section{Introduction}

In the context of a sharp increase in the role of national, ethnic factors, the scientific understanding of this phenomenon becomes extremely important as an integral element of the system of interethnic communication in which ethnic and ethnocultural processes take place.

The Sakha people, who were formed as a Turkic ethnic community before the arrival of the Russians, are undergoing further evolution in their ethnic development. In the process of interethnic contacts, Sakha has an ethnic identity, national self-awareness, and a national ideology is born. It should also be noted that in the process of interethnic contacts, a variety of culture of an ethnic group, its national forms, arises. It is known that already in the pre-revolutionary period, the emerging Yakut ethnic intelligentsia used ethnicity as a consolidating factor in the development of the Sakha people.

Yakutia is the largest constituent entity of the Russian Federation, with an area of three million square kilometers, one fifth of the entire territory of Russia. It is all located in the permafrost zone.

The Republic of Sakha (Yakutia) is one of two regions in the east of the Urals (along with the Republic of Tyva) where Russians do not make up the majority of the population. According to the 2010 census, there are about $49 \%$ of Sakha people in the republic, and about $37 \%$ of Russians. Sakha prevail in 26 out of 35 districts of the republic. For comparison - in Buryatia, according to 2010 , there are $64.9 \%$ of Russians, in Khakassia $81.7 \%$. During the years of reforms, about 200 thousand people left Yakutia (most of them - Russians, Ukrainians and Belarusians) [1].
For 385 years Yakutia has gone through all stages of development together with the Russian state. Over time, this remote eastern outskirt developed into a developed industrial and agricultural region in the north-east of the country. Moreover, the peoples of Yakutia managed to preserve their national identity - territory, language, traditional culture in the huge multi-ethnic Russianspeaking ocean.

The traditional culture of the Sakha people with its features characteristic of the population of the steppe south of Siberia, anthropological and linguistic data, ethnogenetic legends show a complex and heterogeneous origin of the Sakha. They belong to the Turks, but they included both the Evenk (Tungus) population of taiga Siberia and the Mongolian element from the Baikal region.

\section{Materials and methods}

Recently, among the urban population, we observe communication between young people not in their native language, but more in Russian. The older generation speaks the Sakha language more. But if we take it as a whole, the Sakha language, although it does not have the full functions of the state language, is widely used in all spheres of the life of the Sakha people. The interaction of the Sakha and Russian languages of the peoples of the North creates a linguistic situation in the republic that is unlike others. The peoples of the North speak at least three languages - their own national, Russian and Sakha.

A.A. Vinokurova explains, "the indigenous rural population clearly separates the language of communication from the language of instruction, considering the national language as native in the sphere

\footnotetext{
Corresponding author: kysylbaikova@mail.ru
} 
of communication, and Russian as a means of teaching. The rural population is characterized by the desire to preserve national-Russian bilingualism in the state secondary school. Despite this, the linguistic processes here are ambiguous, since even with the existing teaching system, there is a weak command of colloquial speech in Russian. This means that many vital functions still remain with the Sakha language" [2].

It should be clarified that national self-awareness is manifested in one or another people, regardless of what language he began to speak later.

In this regard, D.G. Bragina notes that "in the process of interethnic contacts, ethnic identity is formed in Sakha, the foundations of national self-awareness are laid, and a national ideology is emerging. And what is very important, in the process of interethnic interaction, the diversity of the culture of the ethnos, its national forms, arise. The most important factor in ethnic development in the period under review is the etatization of the Sakha society within Russia. One of the peculiarities of the relationship between the Sakha and the Russians was that the latter were mainly viewed as bearers of power. Thus, we are talking about interethnic contacts between peoples standing not only at different stages of socio-cultural development, but also officially of different status" [3].

It can be concluded that the Sakha people still rely heavily on certain stereotypes of behavior that govern human activities in public life. They are mostly rural residents, in everyday life they are closely connected with the environment, they contribute to the preservation and existence of elements of traditions and customs, they respect their native culture. Ethnic symbols are mostly preserved in family and household rituals associated with significant events. This occurs mainly in rituals aimed at maintaining fertility and material well-being. Thus, respect for the native culture belongs to the most stable area of ethnic identity.

According to the interesting process of the development of the Sakha language, we decided to consider its component by the example of the study of the concept in the consciousness of the speakers of a particular language. In our case, we have chosen the concept "culture" in the linguistic consciousness of the Sakha language speakers.

In connection with the rapid development of the ideas of cognitive science in linguistics, the issues of conceptualization are gaining relevance and significance in recent years. The cognitive mechanism of a person can be understood precisely through language, with the help of language; therefore, the study of this problem in language becomes inevitable.

Learning a language from different positions, namely from the point of view of a cognitive approach, helps to study the person himself: his intellectual, mental, social, ethno-national and other components. In this regard, a person becomes the center of attention of many studies, and the center of attention of linguists is becoming the human language.

Concept is one of the basic and important issues in cognitive linguistics. This term is used in philosophy, cultural studies; it is widely used in linguistic and cultural studies, psycholinguistics, ethnopsycholinguistics, linguodidactics, etc.

Recently, psycholinguistic and ethnopsycholinguistic studies of linguistic consciousness, the study of the image of the world of an ethnic group are a new integrated approach. This approach, used in our study, differs in that it is aimed at identifying the ethnocultural specifics of the linguistic consciousness of representatives of various linguocultural communities. In the study of the concept "Culture", we use linguistic, cognitive, and cultural approaches.

It is well known that each language in its own way divides the world and determines a way of conceptualizing reality that is unique only for a given linguistic culture. On the other hand, on the peculiarities of the linguistic perception of reality and the linguistic consciousness of the speakers of one or another language, an indelible stamp is imposed by the culture within which the given language was formed and functions.

The study of the conceptualization of culture organically fits into the context of modern anthropocentrically oriented directions of linguistics, considering the importance of the category of culture for the life of all mankind and the insufficient development of the problem of conceptualization of culture both in general and in the minds of carriers of different ethnocultures. In the era of globalization, there is a need to return to our roots, as a result, the study of the national and ethnic becomes relevant.

In our research, we adhere to the opinion of L.G. Ionin, who analyzed and researched in detail the linguistic development of the word "culture" over several centuries. He believes that "in modern European languages, four basic concepts of the word "culture" can be distinguished:

- abstract designation of the general process of intellectual, spiritual, aesthetic development;

- designation of the state of society based on law, order, gentleness of morals, etc.; in this sense, the word "culture" coincides with one of the meanings of the word "civilization";

- an abstract indication of the peculiarities of the mode of existence or way of life inherent in some society, some group of people, some historical period;

- abstract designation of forms and products of intellectual and, above all, artistic activity: music, literature, painting, theater, cinema, etc.; especially this sense of the word "culture" is most widespread among the general public [4].

At present, many foreign researchers understand "culture" as a mixture of spiritual and material values and qualities that are offered by society and they also characterize the level of its development. Signs of differences between material and spiritual cultures appear [5-7].

\section{Results and discussion}

The rich and distinctive culture of Yakutia is rightfully the national heritage of Russia. The preservation and 
further development of the unique cultural and spiritual heritage of peoples, the reflection of culture in the linguistic consciousness of the Yakut language speakers are actual issues for the study of the concept we have chosen.

To select the stimulus words corresponding to our concept, we made a survey of dictionary definitions. A total of 50 dictionary definitions were analyzed in order to identify the keywords of the definition of culture. Analysis of the definitions from the dictionary entries of the Sakha and Russian languages made it possible to identify the following stimulus-words of the concept "culture": "culture", "tradition", "civilization", "language", "science", "history", "folklore", "literature", "art", "religion", "education", "sport", "spirituality", "humanism", "upbringing".

2000 native speakers of the Sakha language took part in the associative experiment; they were offered a questionnaire for filling out associations, consisting of 15 stimulus words defining the concept "Culture" and words that are not related to culture. The use of the field method of research allowed us to determine the components of culture, reflecting the structure of the cognitive system-forming mechanism based on the professional ethnocultural code.

There were residents of rural areas among the Sakha language speakers. The inclusion of rural residents is based on the research that in villages where most of the population is represented by Sakha people, they mainly speak their own language, without combining with Russian, they are prominent representatives of the Sakha linguistic culture. Representatives of rural areas were mainly employees of various organizations, structures, as well as elderly people.

The place of the experiment: Yakutsk, Vernevilyuisky, Vilyuisky, Khangalassky, MeginoKangalassky, Namsky, Amginsky, Churapchinsky, UstAldansky districts of our republic, Khatassy, Zhatay on the territory of the urban district "City of Yakutsk". The period of the free associative experiment is 2007-2012. The age of the respondents is 25-65 years old. Education of the respondents is higher and secondary. Social categories of respondents are representatives of diplomatic missions, teachers, businessmen, missionaries, volunteers, tourists, respondents of various specialties, respondents of various social categories, students.

The form of a free associative experiment - the experiment was carried out in the form of a written questionnaire, in which the respondents were offered the stimulus words of the concept "Culture". It should be noted that in the form of a questionnaire, in addition to the stimulus words of the concept, there should be words that are not related to the concept under study. This is done so that the respondent does not guess which concept is being investigated. The respondent's action in the experiment is in the process of a written questionnaire, the respondents should answer, without hesitation, the first word or phrase that comes to mind is a reaction. The result for the experimenter is that as a result of the study, the experimenter receives a fairly large number of reactions to stimulus words, which are classified based on specific goals and objectives. The result is the identification of nuclear and peripheral signs of the concept under study, which makes it possible to draw generalizations and conclusions about the identified features and differences, considering the national linguistic consciousness. The response time is 23 seconds per one stimulus word.

In total, 22201 reactions were received from the Sakha language speakers.

The semantic analysis of reactions shows us how deeply the Sakha language speakers understand culture, its meaning, function, properties.

Since ancient times, the Sakha people have valued one's moral qualities, personal dignity, honor, reputation. To be a cultured person in the understanding of the Sakha is to lead a healthy lifestyle, admire the beauty of nature, be in harmony with it, be an exemplary family man, respect elders, honor the memory of ancestors, observe the customs and traditions of your people, have high morality, be a man of honor.

In modern life, a cultured person in the understanding of the Sakha must be intelligent, educated, well-read, visit the theater, observe the limits of decency (ideal behavior), understand art, but at the same time respect the customs of their country. That is, any people should develop culturally along with the whole world, know world culture, keep up with it, but not lose the features and characteristics of their own culture.

It cannot be argued that the reactions of the Sakha language speakers are focused only on their traditions and customs. The influence of the culture of highly developed countries on the life and culture of the Sakha people is also observed.

To analyze the data of an associative experiment to identify nuclear and peripheral features, as well as to represent the structure of the concept under study, we distinguish the following semantic zones following Yuriy Karaulov:

1) who (the person associated with the stimulus word);

2) what (an object associated with a stimulus word);

3) which (includes constant (integral) features, considered from the perspective of an outside observer);

4) what (evaluative characteristics within the scale "good - bad");

5) this (quasi-definitive constructions in which the pronoun "this" plays the role of a hypothetical link);

6) do (action associated with a stimulus word);

7) where (the place associated with the wordstimulus);

8) when (the time period associated with the stimulus word) [8].

As a result of the analysis of the reactions of the Sakha language speakers and their distribution according to the "semantic gestalt" method by Yuriy Karaulov, we identified the conceptual signs (Table 1). 
Table 1. Conceptual signs of the concept "Culture".

\begin{tabular}{|l|l|l|}
\hline No. & Conceptual signs & $\%$ \\
\hline 1 & Folklore & $17.8 \%$ \\
\hline 2 & Art & $11 \%$ \\
\hline 3 & Science & $11.2 \%$ \\
\hline 4 & Literature & $10.2 \%$ \\
\hline 5 & Language & $8.1 \%$ \\
\hline 6 & Sport & $7.6 \%$ \\
\hline 7 & Education & $7.7 \%$ \\
\hline 8 & Faith & $5.3 \%$ \\
\hline 9 & Soul & $4.8 \%$ \\
\hline 10 & Geography & $4.5 \%$ \\
\hline 11 & Family & $2.7 \%$ \\
\hline 12 & Attribute & $2.1 \%$ \\
\hline 13 & Informational technologies & $1.9 \%$ \\
\hline 14 & History & $1.5 \%$ \\
\hline 15 & Attribute of nationality & $1.4 \%$ \\
\hline 16 & Time & $1.0 \%$ \\
\hline 17 & Quality & $0.3 \%$ \\
\hline
\end{tabular}

According to the data obtained, the core of the concept "culture" in the linguistic consciousness of the Sakha language speakers is "folklore". It included such reactions as olonkho (Yakut heroic epic), folklore, Sakha language, rite, ysyakh (Yakut national holiday), ritual.

The first layer of the concept "culture" is represented by the signs Art, Science, Literature.

The second layer is Language, Sport, Education.

The third layer is Faith, Soul, Geography, Family.

The core of the concept under study is folklore, as the basis of the national culture of the Sakha people. According to the data obtained, we see that folklore, on its long path of development, comprehensively reflecting the history, life and way of life of the people, has developed its own spiritual and aesthetic specific traditions. Its traditions were passed down orally from one person to another, from one generation to the next. The core of the concept "culture" is folklore, an important spiritual heritage, and a source of development of literature and culture of the people. The folklore of the Sakha people is known for being rich and diverse. Among its various genres, an outstanding place belongs to the heroic epic olonkho.

It is impossible to imagine the culture of the Sakha without folklore. The genre composition is rich and varied: olonkho, fairy tales, songs, stories, historical legends, riddles, tongue twisters, proverbs, and sayings, etc. Folklore has its own specific features: tradition, orality, collectivity, and variability. Oral poetry emerged simultaneously with the ethnic formation of the Sakha people.

\section{Conclusion}

To sum up the research, we can say that psycholinguistic and ethnopsycholinguistic studies of linguistic consciousness, as well as the study of the image of the world of an ethnic group, are a new integrated approach aimed at identifying and comparing the ethnocultural specifics of the linguistic consciousness of representatives of various linguocultural communities. In this context, linguistic consciousness is considered as a set of conceptual, perceptual, and procedural knowledge of a representative of a certain linguoculture about the objects of the surrounding world or as a union of images of consciousness realized through various linguistic means (words, free and stable phrases, associations, etc.).

In the study of the concept we have chosen, linguistic, cognitive, and cultural approaches are applied. The approach used and the results of the conceptualization of "culture" in the national linguistic consciousness of the Sakha language speakers make a certain contribution to psycholinguistics, ethnopsycholinguistics, cognitive linguistics, language theory, the theory of intercultural communication, cultural linguistics in the direction of studying the ethnocultural determinism of linguistic consciousness and its constituent images.

The method of field description of the concept structure made it possible to apply the following research methods: associative experiment as a means of access to images of linguistic consciousness, Yuriy Karaulov's "semantic gestalt" to identify the nuclear and peripheral features of the concept. It should be noted that associative material reveals not only individual, but also normative, figurative components of conceptual content, subject to a mass experiment.

An analysis of the data obtained based on the results of a free associative experiment showed that the structure of the studied concept clearly reflects the ethnocultural features of the presentation of the Sakha language speakers about culture.

In the linguistic consciousness of the Sakha respondents, the obtained data establish that in order to fully master the concept and content of their culture, the bearer of the cultural code must necessarily know about the traditional components of their native culture, respect customs, and be able to accept the peculiarities of other cultures.

As a result, we can conclude, that culture is a universal concept. Culture is reflected in language, language is culture. Language is one of the most specific components of any ethnic culture. Ethnicity makes a particular culture special. The study of national linguistic, ethnic consciousness allows us to formulate the image of the world of carriers of a particular linguistic culture. It is consciousness that is especially important for interpreting thoughts and conveying the way of thinking.

The concept "culture" is an ethno-labeled semantic formation; its structure clearly reflects the ethnocultural features of the presentation of the Sakha language speakers about culture.

This research was funded by grant No. 075-15-2021-616 of the Government of the Russian Federation for the project «Preservation of Linguistic and Cultural Diversity and Sustainable Development of the Arctic and Subarctic of the Russian Federation» 


\section{References}

1. E.A. Borisov, Russia's National Policy: A View from the Region, retrieved from: https://glava.sakha.gov.ru/afisha/front/view/id/3 82332

2. U.A. Vinokurova, Value orientations of the Yakuts in the conditions of urbanization (Novosibirsk, Nauka, 1992)

3. D.G. Bragina, Ethnic and ethnocultural processes in the Republic of Sakha (Yakutia): 70-90s of the XX century (Novosibirsk, 2003)

4. L.G. Ionin, Sociology of culture (Moscow, Logos, 1998)

5. S. Bassnett, Studying British Cultures (N.Y., Routledge, 2003)

6. J. Giles, Studying Culture: A Practical Introduction (Oxford, Blackwell, 2008)

7. J. Storey, Cultural Studies and the Study of Popular Culture: Theories and Methods (Edinburgh, University Press, 2010)

8. Yu.N. Karaulov, Indicators of national mentality in the associative-verbal network, Ling. consc. and the im. of the world (Moscow, Institute of Linguistics of the Russian Academy of Sciences, 2000) 